\title{
Skills and professional practices for the consolidation of the support group model to foster families
}

\section{Competencias y prácticas profesionales para la consolidación del modelo de apoyo grupal a las familias acogedoras}

M. Àngels Balsells, Department of Pedagogy and Psychology, University of Lleida, Lleida, Spain Nuria Fuentes-Peláez, Department of Research methods and Diagnostic in Education, University of Barcelona, Barcelona, Spain

Maribel Mateo, Department of Research methods and Diagnostic in Education, University of Barcelona, Barcelona, Spain

J. M. Torralba, Department of Social Work and Social Services, University of Barcelona, Barcelona, Spain

Verónica Violant, Department of Didactics and school organization, University of Barcelona, Barcelona, Spain

CONTACT M. Àngels Balsells balsells@pip.udl.cat

\section{ABSTRACT}

The research presented here is justified by the lack of tradition in Spain with regards to socioeducational intervention programmes based on training and group support, as well as the proven benefits of these methods in foster care. It addresses the need to go deeper into the acquisition and consolidation of the core professional competences for running socioeducational groups with foster families. After a process of participatory action-research with 39 professionals from the Child Protection System from different regions of Spain, we see an improvement in the development of the competences necessary to establish a supportive relationship with families, management and group dynamics, as well as the crystallization of attitudinal changes in professional practices. Data have been collected on the basis of methodological complementarity and a pre-test-post-test design that has identified and explained the changes in the evolution of competences and professional practices.

KEYWORDS: Competency-based training; professional practice; kinship foster families; group support mode 


\section{RESUMEN}

La escasa tradición en España en realizar intervenciones socioeducativas basadas en la formación y el apoyo grupal, así como los beneficios demostrados de los mismos en los acogimientos familiares, justificaron el desarrollo de la investigación que se presenta. Se aborda la necesidad de profundizar en la adquisición y consolidación de las competencias profesionales fundamentales para la acción socioeducativa grupal con familias acogedoras. Tras un proceso de investigación acción participativa con 39 profesionales del Sistema de Protección de diferentes CCAA, se constata una mejora en las competencias para establecer una relación de ayuda con las familias, para la gestión y la dinámica de grupos, así como la cristalización de cambios actitudinales en las prácticas profesionales. Los datos se han recogido en base a la complementariedad metodológica y a un diseño pretest-postest que ha permitido identificar y explicar cambios en la evolución de competencias y prácticas profesionales.

PALABRAS CLAVE: Formación por competencias; prácticas profesionales; familias acogedoras extensas; modelo de apoyo grupal 


\section{Kinship foster care in Spain}

The fostering of children in kinship families existed in Spain long before the proclamation of law 21/ 1987, but the law made this practice a formally recognised form of child protection. Regarding the child protection system, a considerable number of children are in residential care. Compared with other Western countries, there are considerable difficulties related to placing a child in a nonkinship foster family. The figures for Spain are approximately $45 \%$ for residential placements, $45 \%$ for kinship care and $10 \%$ for non-kinship foster families (Montserrat, Casas, \& Malo, 2013). Kinship fostering is the most common type of fostering in Spain (Del Valle, López López, Montserrat, \& Bravo, 2010) as well as in other countries (Berrick, Barth, \& Needell, 1994; Broad, 2004; Geen, 2003). In Spain, 85\% of fostering occurs within the kinship family, which is a much higher proportion than in other countries (Del Valle \& Bravo, 2003).

Most of the Spanish research conducted on kinship care is fairly recent. Montserrat (2012) presents a systematic review of kinship care research in Spain. This review establishes that (a) the distribution by gender is fairly equal in both kinship and non-kinship care (Del Valle, Álvarez-Baz, \& Bravo, 2002; Del Valle, López, Montserrat, \& Bravo, 2009; Montserrat, 2007); (b) children in kinship care are fostered from a younger age than those fostered in non-kinship care (Montserrat, 2007; Palacios \& JiménezMorago, 2007) and (c) kinship foster carers tend to be older (more than $70 \%$ are grandparents), to be economically worse off and to have a lower level of education than non-kinship carers (Amorós et al., 2005, 2012; Del Valle et al., 2002, 2009; Molero, Moral, Albiñana, Sabater, \& Sospedra, 2007; Montserrat, 2007; Palacios \& Jiménez-Morago, 2007).

The polemic beginnings of kinship foster care have been silenced by the benefits reported in the progress of fostered children (Geen \& Berrick, 2002). Recent studies demonstrate more advantages (Montserrat, 2012) than drawbacks for this type of fostering (Farmer, Selwyn, \& Meakings, 2013). Among the advantages of family fostering are the continuity of personal, family and social history and fewer traumatic phases (Child Welfare League of America, 1994; Ehrle \& Geen, 2002) and changes with kinship fostering than with outside fosterers (Balsells, Fuentes-Peláez, Mateo, Mateos, \& Violant, 2010). These benefits, together with the willingness of extended families to look after 'their' children (grandchildren, nephews and nieces), which saves both time and money for authorities, have contributed to the increase in this phenomenon. As a result, kinship foster care is currently the first option when a child is separated from his/her nuclear family (Mateos, Balsells, Pastor, Vaquero, \& Mundet, 2015).

Social work in Spain has a strong tradition of individualised methodologies, and kinship foster care is usually conducted using only these methodologies. However, although individual attention is appropriate for the diagnostic stage, it has certain limits in the development of a case plan. Currently, authors are seeing growing demand from teams of professionals for methodologies that allow groups to evaluate and support kinship foster families.

\section{Support groups in kinship foster care}

More than 20 years ago, Hegar and Scannapieco (1999) discussed a change in the model of kinship foster care in Anglo-Saxon countries towards a more holistic view that focused on family interventions more than on children's needs. This change of perspective implied the 
collaborative involvement of all those participating in foster care and family development programmes.

In many family support programmes, the suggested intervention strategy is a group strategy. Several studies have indicated that group intervention guarantees the maintenance and wellbeing of kinship fostering (Burnette, 1998; Leos-Urbel, Bess, \& Geen, 2002). Research based on evaluations of family group intervention programmes have shown that working in groups is beneficial to those who participate and helps to reduce social isolation and improve the social network and relationships between family members. Participants receive support and guidance for situations specific to parenting, thus reducing risk situations (Amorós, Balsells, Fuentes-Peláez, Mateos, \& Pastor, 2011; Burnette, 1998; Kropf \& Kolomer, 2004; Leos-Urbel et al., 2002; López-Larrosa, 2009; Price et al., 2008; Vacha-Hasse, Ness, Dannison, \& Smith, 2000).

In the case of kinship fostering, group work aimed at kinship foster parents and foster children helps the participants learn more about their own situation (Amorós, Fuentes-Peláez, \& García, 2004; Balsells et al., 2010; Kropf \& Kolomer, 2004; Parra-Ramajo, 2012), promotes communication between families (Amorós, Fuertes, \& Roca, 1994; Amorós et al., 2004; Mateos, Balsells, Molina, \& Fuentes-Peláez, 2012) and offers families the opportunity to exchange experiences, seek mutual help and reduce isolation (Kropf \& Kolomer, 2004; ParraRamajo, 2012). It also encourages them to form new relationships, thus empowering the participants (Vacha-Hasse et al., 2000) and reducing situations of risk and vulnerability in foster care (Kropf \& Kolomer, 2004). Therefore,

group learning sessions are crucial to develop the mechanisms for family resilience, reducing social isolation by connecting kinship foster families with other families in the same situation. This helps them to be aware of their situation, to be valued by other people and professionals, and above all, to take a step forward in the right direction towards resilience by being able to help other families. (Fuentes-Peláez, Balsells, Fernández, Vaquero, \& Amorós, 2014, p. 8)

For these reasons, we can affirm that group work is an effective method to increase personal and family well-being.

The few support programmes published for kinship foster families and foster children that have been used on a national level in Spain (Amorós et al., 2005, 2012; Amorós, et al., 1994; Amorós, Palacios, Fuentes-Peláez, León, \& Mesas, 2002; Balsells et al., 2010) have a threefold aim. First, these programmes aim to provide information about the situation of foster care, its implications, the most frequent problems and the resources available. Second, they aim to develop in the participants a series of skills that will allow them to face everyday situations produced by this form of foster care, by improving their social resources and avoiding isolation. Finally, kinship foster families are emotionally predisposed to accept certain circumstances linked to the child's background and the relationship with the biological family, thereby personally strengthening the foster carers in their task and reinforcing their existing capacities. 


\section{Professional skills for support group sessions}

The requirements of these programmes and of working with groups are challenging for social workers. One of the first things to consider is the role of the social worker in group sessions. The social worker helps the participants reflect on their situation and tries to involve them in their own personal situation and in the situations of the other group members, thus making them all equally responsible for the group work. Therefore, this professional practice requires specific skills. The present study uses as a reference the definition provided by Echevarría (2005) who understands this skill as a body of knowledge, procedures, capabilities and attitudes that are mutually complementary so that participants know 'how to be' and 'how and what to do' to act effectively in a professional situation.

In group programmes for foster care, the following skills are required: (a) professional knowledge of group management and group dynamics; (b) procedural - knowledge of how to encourage communication using new technologies and (c) social - being accessible to other professionals in their team and to the participants themselves to demonstrate the necessary listening skills and empathy and to provide a supportive relationship.

Durán-Aponte and Durán-García (2012) find that the most necessary skills are those related to ethical commitment, personal skills, teamwork and professional responsibility. The development of these social skills adds a human quality to professional practice and a sense of social justice similar to the commitment acquired by professionals who work in the field of child protection. Given this context, scientific research highlights the need for the necessary skills for group management as well as the personal and social skills that provide a human touch to relationships with foster families.

\section{Objectives}

The aims of this study were the following:

(1) To evaluate the skill development of the professionals involved with regard to (a) ways of behaving to establish a supportive relationship with the families, (b) management skills and group dynamics and (c) knowledge and personal social skills to work in kinship fostering.

(2) To observe the changes in the practice of professionals who have been leaders in support groups for kinship foster families (by using the kinship family support programme) and have taken part in the process of cooperative action-research.

\section{Research methodology}

There is a lack of tradition in Spain of professional interventions based on group work with foster families. Therefore, there has been little need for professional skills to successfully guide this type of intervention. This situation has made it necessary to propose research aimed at change in professional practices and the acquisition of such skills. Taking the approach of cooperative action-research, university staff and child protection staff took part in the study with the aim of transforming the way professionals support foster families. Cooperative actionresearch is considered a process of change and a tool for transformation (Bartolomé, 1986; Bartolomé \& Anguera, 1990). Involving social workers in the process makes them active 
members who are more sensitive to change while the study is proceeding and in the subsequent implementation of the outcomes and the resulting programmes.

\section{Participants}

The sample for this study was professionals who work with children and who are responsible for follow-up with kinship foster families. Thirty-nine professionals used the group support programme called the Training Programme for Kinship Family Fostering (PFAFE) (Amorós et al., 2005,2012 ) with fostering families in their social service network. The PFAFE programme aims to improve the personal and parental skills of foster parents by paying attention to specific needs related to kinship fostering with a view towards promoting family resilience (Amorós et al., 2009; Fuentes-Peláez, Amorós, Balsells, \& Pastor, 2010). Of the professionals involved, 83.8\% were women and $16.2 \%$ were men. The professionals who applied PFAFE were mostly psychologists (18) and social workers (10), while a smaller number were social educators (6) and educators (5). Of those involved, $21 \%$ had less than one year of professional experience in child protection, $15 \%$ had between 1 and 2 years of experience, $25 \%$ had between 3 and 5 years, 18\% had between 5 and 10 years and the rest (21\%) had more than 10 years of experience.

\section{Methodology}

The study adopted a complementary methodology. Quantitative data were collected by means of a questionnaire about professional skills, and qualitative data were collected from the discussion groups. Both methods were applied at different times in the process because it had a pre-test post-test design in which the analysis attempts to identify and explain changes in skills and professional practices.

(1) The questionnaire about professional skills included 12 closed items with a 5-point Likert scale (0-5 from disagreement to agreement). For each of the items, the professionals evaluated the importance of the skills (degree of importance of the skills needed to work with kinship foster families) and their perception of their individual level of the skill (degree of competence in relation to the professional's work with kinship foster families). Two largegroup skills were explored: the ability to establish a supportive relationship with the families (items 1 (ability to show coherence and authenticity as a professional and as an individual), 2 (ability to show empathy towards the foster families and their situation), 3 (personal ability to show assertiveness in communicating with the foster families), 4 (personal ability to show respect and understanding towards the foster families) and 5 (ability to accept and welcome the foster families and their situations)) and skills and abilities in group management and dynamics (items 6 (mastering group techniques and dynamics), 7 (motivation to use group techniques and dynamics), 8 (ability to speak in public), 9 (ability to lead groups), 10 (ability to organise learning and time keeping), 11 (social skills to mediate and negotiate) and 12 (ability to use new technologies)).

(2) The script from the group discussion highlighted the following aspects: characteristics relevant to the pre-selection phase, attraction and motivation; development of the programme; usefulness of the programme; degree of satisfaction; usefulness and continuity of the programme and changes in professional intervention and in the families. There were four 
further areas: general maintenance of the outcome of PFAFE; concrete aspects that have changed and those that have remained; the professionals' opinions of the methodology of PFAFE and incorporation of the group methodology in intervention/support for kinship foster families.

\section{Procedure}

Eight training courses for professionals (CFF) were conducted in which the professionals were trained by one member of the research team on how to manage PFAFE. All of the CFFs followed the contrast design to further their learning through experience in professional skills (Pastor, Amoros, Molina, \& Balsells, 2008). After the professionals were trained, they took part in developing seven PFAFE training groups with kinship foster families. PFAFE is designed for group application with between 8 and 16 participants and 2 professionals for each session. It consists of an introductory session followed by 11 sessions. The sessions were held fortnightly and lasted two and a half to three hours. The programme included the most relevant socioeducative aspects of fostering in kinship families. Thirty-nine professionals were distributed into seven PFAFE groups. To provide them with the opportunity to participate, each professional led a minimum of two PFAFE sessions and directly participated in a minimum of six PFAFE sessions. Thus, in most of the groups, the sessions were run by three professionals instead of two professionals.

Data were collected at different times during the investigation process. The skills questionnaire was completed by the professionals at three different times: before beginning the CFF (stage 1 - S1), when finishing the CFF (stage 2-S2) and after conducting the PFAFE (stage 3-S3) with the foster families. The discussion group was also held at different times. The first group coincided with the end of the PFAFE (stage $3-$ S3) and the second group was held six months later (stage 4 - S4). Seven discussion groups took part at stage $3-\mathrm{S} 3$, and seven more participated at stage $4-S 4$. The same researchers who led the CFF were the discussion group leaders. All of them kept a register of the participants' characteristics and a summary of the most important issues addressed. The following guidelines were used: introduction, explanation of the aims of the meeting and a discussion of the norms; the role of the coordinator (to present, to keep order, to question and to summarise); the role of the assistant (to take notes on contributions, to collect the main ideas, to help the coordinator ensure that all of the material is covered and summarised); audio recording (after requesting agreement to record); confidentiality and creating an atmosphere of free participation and respect for the opinions of others. The discussion group leaders asked questions about issues they considered necessary to expand on the information that emerged from the group in a spontaneous fashion. All of the group discussions were recorded for subsequent transcription and analysis.

\section{Analysis}

Data analysis was conducted by means of two complementary approaches.

(1) Analysis of discussion group content using the Altas-Ti-V6.2 program in professional software qualitative data analysis (QDA). A hermeneutic unit was created that included dimensions, categories and subcategories. The system of categories was developed in various stages: three discussion groups were analysed by five judges (researchers from the team) until 
a set of categories was established. Once the set of categories was obtained, a system of double judges was adopted to analyse each unit. Each pair of judges (researchers from the team) individually read, analysed and coded the transcripts of the discussion group. If there were discrepancies, a consensus was obtained. Finally, the codification data were extracted using the program Atlas-Ti-V6.2.

(2) Descriptive analysis of the questionnaire about professional competences using the program SPSS-V.15 (Statistical Package for Social Sciences). Frequency tables from each of the variables from the questionnaire and contingency tables of the relationship of the participation of the professionals at each stage were made (stage 1 - S1, end S2 and delayed S3). Links between the level of importance of the skill and the level of the participants' own ability were analysed at stages S1-S2 and S2-S3 (Pearson's coefficient correlation). The average level of importance given to each skill was contrasted with the professionals' own ability in each skill at stage S1-S2. Finally, the average rates given to each personal skill were analysed (Wilcoxon's variation range) to compare the professionals' evaluations of their skills at stages S1-S2 and S2-S3.

\section{Research findings}

\section{Characterisation of participants}

The methodology most frequently adopted by professionals with kinship foster families is individual intervention (70\%), usually by means of interviews, home visits and monitoring. Only $30 \%$ of the professionals have used group work with kinship foster families, and only sporadically. These data confirm the lack of tradition regarding the use of group methodology among child protection professionals as well as the predominance of individual support for families.

\section{Professional skills: ability to establish a supportive relationship with the families}

In the area of skills and approaches to establishing a supportive relationship with families, the results of the questionnaire show that in perceptions of the domains of each of the skills analysed, there were no significant changes between stages S2 and S3. However, average differences were found between stages S1 and S2 according to levels of statistical acceptance. The differences observed in these skills can be seen as an increase in the perception domain at stage S2. This increase refers to an increased awareness of social and communicative skills by the professionals when addressing foster families, thus giving them a self-image of greater coherence and authenticity both as professionals and as individuals (Sig. $=0.0040$ ). This result is also reflected in the feedback given by the foster families regarding the quality and level of communication between themselves and the professionals (Sig. $=0.0150$ and Sig. $=0.0140$ ). These competences refer to their ability to establish interpersonal relationships, to act assertively, to show responsibility and to be cooperative and flexible in teamwork. Other studies (Camperos, 2008; Fortín \& Legault, Pedraja, \& Rivera, 2006; Vargas, 2000) have referred to social skills such as analytical capacity, working on a team, negotiating, problemsolving, communication and leadership skills. With regard to the importance given to each skill, no significant changes were found in the professionals in the PFAFE programme between stages S1 and S2 and stages S2 and S3. Professional competences: abilities and skills in group 
management and group dynamics According to the perception of mastery in each of the analysed competences, there were no signifi- cant changes between stage S2 and stage S3. However, there were changes between stage S1 and stage S2 in some competences according to the statistical significance level. We therefore conclude that changes occurred after the professionals' training course (CFF). The professionals felt that their competences improved relating to motivation $(\mathrm{Sig} .=0.0120)$, group dynamic techniques $(\mathrm{Sig} .=0.0180)$ and leadership (Sig. $=0.0380)$. They were able to manage the group better and felt they could directly involve the kinship families in everything that affected them in their social-educational care of the foster children. The social workers also felt that they were better able to speak in public (Sig. = 0.0040), which helped in their communication with the families and in managing the group dynamics. With time, they gained more confidence as group leaders to carry out the socioeducational practices with the participating families. When examining the level of importance the professionals gave to each skill, we found that the professionals who adopted the PFAFE did not note significant changes in the skills analysed at stages S2 and S3, but they did see differences in the means of the competences analysed in the level of statistical significance between stages S1 and S2. These increased rates of the perception of improvement in public speaking (Sig. $=0.0370$ ) and adopting new technologies (Sig. $=0.010$ ) is connected to the ability to communicate in public and adaptation to communication technologies. These improved perceptions can be seen as a way to make the participating families more involved and more satisfied with the group sessions. These results are consistent with those found in the DeSeCo Project (Rychen \& Salganik, 2003) and confirm that knowing how to behave, what to do and how to do it are more important than theoretical knowledge. The competences refer to special training for interaction in diverse groups and encouraging autonomy when working with individuals as essential socio-cultural tools that complement the theory. The same authors (2003) note that in turn, social competences give people the ability to face complex situations and to rely on and mobilise psychosocial resources, including attitude, in any particular circumstance.

\section{Other professional competences: aiming to clarify practices}

The methodological complementarity of the study design made it possible to obtain wider results than those obtained in previous studies by means of a questionnaire. Through a content analysis of the discussion groups, other competences can be identified that have been improved in the social workers' practice by the participatory training. Questions that refer to attitude, concepts and abilities reinforce the changes in group management and dynamics as well as personal skills when relating to the families.

The social workers were asked the following questions: How do you rate your relationship with the foster families participating in the PFAFE? How do you rate your relationship with the other professional(s) in charge of the session? Has anything changed in your perception of your work with the foster families who participated in the PFAFE? Responses refer to three specific types of competence. See Table 1 , system of categories and subcategories analysed at stage S3 with examples of textual quotes.

Table 1. System of categories and subcategories analysed at stage S3 with examples of textual quotes.

\begin{tabular}{|l|l|l|l|l|}
\hline Category & Subcategory & Example from the categories & Number \\
\hline
\end{tabular}




\begin{tabular}{|c|c|c|c|}
\hline & & analysed & of quotes \\
\hline \multirow[t]{2}{*}{$\begin{array}{l}\text { Competences of } \\
\text { attitude }\end{array}$} & Need to improve & $\begin{array}{l}\text { 'Family fostering is like an iceberg, } \\
\text { you only see the outside, top part, } \\
\text { when really there is in-depth work, } \\
\text { intense and necessary in } \\
\text { everything concerning kinship } \\
\text { family fostering. The need to } \\
\text { continue training is essential for } \\
\text { our work' }\end{array}$ & 29 \\
\hline & Positive feeling & $\begin{array}{l}\text { 'There's also the feelings the } \\
\text { families send back to us which } \\
\text { make it doubly gratifying, seeing } \\
\text { them respond makes you try } \\
\text { harder' }\end{array}$ & 17 \\
\hline Content skills & & $\begin{array}{l}\text { 'It helped me go over concepts } \\
\text { which I had almost forgotten, it } \\
\text { was useful for me' }\end{array}$ & 6 \\
\hline \multirow[t]{4}{*}{$\begin{array}{c}\text { Competences of } \\
\text { abilities }\end{array}$} & $\begin{array}{l}\text { Experience and } \\
\text { preparation }\end{array}$ & $\begin{array}{l}\text { 'I also think that there's a } \\
\text { relationship between what } \\
\text { happens at the beginning of the } \\
\text { group, not knowing how it will turn } \\
\text { out, how I will manage... and then } \\
\text { afterwards seeing how it has } \\
\text { changed is always positive. Of } \\
\text { course, in the first session you're a } \\
\text { bit lost but then the next is OK ... } \\
\text { like everything, I suppose' }\end{array}$ & 14 \\
\hline & Feelings generated & $\begin{array}{l}\text { 'The first day is very important, the } \\
\text { impression we give trying to } \\
\text { motivate and involve them in the } \\
\text { group. In general I felt relaxed, } \\
\text { sometimes I felt more in command } \\
\text { and at others, less, yes' }\end{array}$ & 11 \\
\hline & Motivation & $\begin{array}{l}\text { 'They've really worked hard, the } \\
\text { people who have given the } \\
\text { sessions and the ones who have } \\
\text { collaborated with them. For most } \\
\text { of the sessions, the four people } \\
\text { who have led them have worked } \\
\text { loads' }\end{array}$ & 15 \\
\hline & Personal competences & $\begin{array}{l}\text { 'More security no, better in... in the } \\
\text { way you feel more capable, a bit } \\
\text { more confidence, you feel more } \\
\text { competent, at a given point, the } \\
\text { sessions go well, people talk, } \\
\text { there's discussion and progress is } \\
\text { made. There's a positive feeling, of } \\
\text { helping, they're really satisfied } \\
\text { with the course: 'it's changed our } \\
\text { way of life at home', 'we wave the } \\
\text { magic wand' }\end{array}$ & 17 \\
\hline
\end{tabular}


(1) Attitude competence: after running the PFAFE program, the professionals gained a better understanding of the difficulties and peculiarities that face each kinship foster family; as a result the professionals recognised their 'need to improve' on the understanding of these families and how to manage the training group to achieve the objectives of PFAFE. The social workers expressed positive feelings about the training they received and their overall experience with the research process. Bass, Shields, and Behrman (2004) agree that without well-prepared professionals, not even the best approaches to kinship fostering can be successful.

(2) Content competences: Some types of content were also identified as being important, such as an awareness of different needs in the kinship foster families: differential roles, the relationship between foster family and parents and rights and responsibilities of the foster carers It appears that skills related to knowledge are relatively easy to develop (Spencer \& Spencer, 1993) and that training is the best way to do so.

(3) Ability competences: the professionals referred to issues that arose in the sessions that had not been included in the questionnaires: experience and preparation, feelings of fear or insecurity and personal skills. The social workers highlighted the necessary competences for successfully managing the group work. These aspects are endorsed by Tobón (2006), who affirms that the dimension of motivation is essential to conducting any programme effectively, including the will to do a job well, a sense of responsibility while doing the job and readiness to learn.

The professionals also reveal the importance of promoting personal skills, as described by Tejada and Navío (2005), to create new expectations to furthering functional mobility, motivation at work and professional and personal advancement.

Six months after the initial stages (S4), when a new discussion group was formed, other categories emerged helping professionals to identify the competences that remained over time and others that emerged in S3. See Table 2, system of categories and subcategories analysed at stage $\mathrm{S} 4$ with examples of textual quotes.

\begin{tabular}{|c|c|c|c|}
\hline Category & Subcategory & Example from the categories analysed & $\begin{array}{l}\text { Number } \\
\text { of quotes }\end{array}$ \\
\hline $\begin{array}{l}\text { Competences of } \\
\text { content }\end{array}$ & Changes & $\begin{array}{l}\text { 'I'm sure that the social workers included } \\
\text { things, but they don't know it yet. They } \\
\text { definitely learnt things, saw their results, } \\
\text { and they're already using them. The thing } \\
\text { is we're not aware of what we're doing, } \\
\text { but I'm sure that in the end we use and } \\
\text { express what we have learnt' }\end{array}$ & 28 \\
\hline $\begin{array}{l}\text { Competences of } \\
\text { attitude }\end{array}$ & $\begin{array}{l}\text { Feelings } \\
\text { experienced }\end{array}$ & $\begin{array}{l}\text { 'It's enrichening. Enrichening, because as I } \\
\text { was saying, you see different ways to work } \\
\text { and it makes it easier of course. It helps a } \\
\text { lot' }\end{array}$ & 23 \\
\hline Competences of & Difficulties & 'Maybe the most difficult part is over, & 21 \\
\hline
\end{tabular}




\begin{tabular}{|l|l|l|l|}
\hline abilities & & $\begin{array}{l}\text { preparing the sessions, learning the lines } \\
\text { and all that. All that's done. And what we } \\
\text { were talking about before, adapting it } \\
\text { instead of 13, 14 or 16 year-olds, to7, 8 or } \\
\text { 11-year olds, which is who we saw' }\end{array}$ & \\
\hline & $\begin{array}{l}\text { Considerations } \\
\text { for the future }\end{array}$ & $\begin{array}{l}\text { 'I don't think the course was done with } \\
\text { much time, at a determinate time, they are } \\
\text { probably ready for this training without us, } \\
\text { really, it could be done with all the families } \\
\text { and at an earlier age' }\end{array}$ & 15 \\
\hline & $\begin{array}{l}\text { Changes } \\
\text { emerging in } \\
\text { the } \\
\text { professional's } \\
\text { approach }\end{array}$ & $\begin{array}{l}\text { 'It was a great effort for me, a lot of work, } \\
\text { personally, I wasn't keen on speaking in } \\
\text { public, so, it was a good personal } \\
\text { experience. At a professional level, working } \\
\text { with the families it's reinforcing individual } \\
\text { work through a group ... At first I wasn't } \\
\text { very at ease with it, but I liked it a lot, } \\
\text { really' }\end{array}$ & 53 \\
\hline
\end{tabular}

Professionals identified changes in their practices, they now incorporate the new skills and they have more confidence when working with kinship foster families.

To summarise, regarding content competences the professionals said that although they were not aware of changes that had occurred, they thought that these changes were still taking place. Regarding attitude competences, as they use a methodology that offers more feedback from the families, this reinforced their positive feelings such as self-confidence and the impression that they had increased their capability to improve their intervention. And, regarding abilities and competences, the social workers expressed difficulties in preparing the sessions and marked points to consider for the future in relation to time and preparation.

These results show how the professionals changed their attitude and highlight what they gained from the training that they received and the experience of working in a group, which increased their motivation. They also mentioned feeling greater self-confidence and selfesteem. With regard to content, they felt that they had improved their skills and had a better understanding of the issues relevant to them as professionals. Finally, they emphasised the need to prepare the sessions well to improve the results and to employ the new methodology adopted. Above all, they felt they had improved their ability to speak in public.

In general, the professionals felt that by acquiring new skills through the use of new approaches such as group work, they had become better professionals. It can be affirmed that achieving and increasing skills becomes an upward-spiral learning process that creates the need for permanent training (Tejada \& Navío, 2005).

\section{Discussion}

The results of this study suggest that group intervention developed with leader training (CFF) and the application of the PFAFE programme can have positive results for all of the participants. These changes are possible because the professionals who lead the programme introduce specific competences that facilitate group work. 
Understanding of the competences required to work with groups was found to have improved after the application of the programme, especially regarding professional skills connected with group work, such as group techniques and dynamics, motivating groups, the ability to speak in public and group leadership. Introducing and improving the use of these skills undoubtedly changed the approach of the professionals. The study confirmed that the predominant method of working with kinship foster families is an individual approach. However, after finishing the PFAFE groups, the professionals who participated in this study made a change from the idea of exclusively individual interventions to the possibility of combining this approach with group work. This change of perspective about group methodology will help to create an atmosphere of collaboration between families and professionals and will result in the provision of better service (Davis \& Day, 2010; Rodrigo, Máiquez, \& Martín, 2011; Rodrigo, Martin, Mateos, Pastor, \& Guerra, 2013).

What has influenced this shift in perspective? Studies show that co-operative research may have had a positive result in motivating change by promoting competences through basic training (CFF) before the initiation of the PFAFE. Cooperative action-research provided selfconfidence and helped to generate shared reflection processes between professionals and academics.

In agreement with Durán-Aponte and Durán-García (2012), the professionals who participated in this study managed to combine both professional and social competences, not only in knowing what to do but also in knowing how to live with and contribute to the lives of others. The results suggest a need to examine the skills training offered to professionals who will work in child protection and who accept the challenge to develop a combination of technical, professional and social skills.

\section{Funding information}

This work was supported by the Spanish Ministry of Science and Technology [grant number SEJ2005-02657], [grant number EDU2011-30144-C02-01]; the Agency for Management of University and Research Grants AGAUR [grant number 2009 SGR 1392].

\section{References}

Amorós, P., Balsells, M. A., Fuentes-Peláez, N., Mateos, A., \& Pastor, C. (2011). 'Aprendre ensemble, grandir en famille' Programme de soutien socio-éducatif. La revue internationale de l'éducation familiale, 30, 61-80.

Amorós, P., Fuentes-Peláez, N., \& García, O. (2004). La formación para el acogimiento en familia extensa. Infancia y Aprendizaje, 27, 447-455.

Amorós, P., Fuertes, J., \& Roca, M. J. (1994). Programa para la formación de familias acogedoras. Valladolid: Junta de Castilla y León y Ministerio de Asuntos Sociales.

Amorós, P., Palacios, J., Fuentes-Peláez, N., León, E., \& Mesas, A. (2002). Programa para la formación de familias acogedoras de urgencia y diagnóstico. Barcelona: Fundación La Caixa.

Amorós, P., Palacios, J., Jiménez, J., Molina, M. C., Pastor, C., Cirera, L., Sánchez, E. (2005). Programa para la formación de acogedores en familia extensa. Barcelona: Fundación La Caixa. 
Amorós, P., Palacios, J., Jiménez, J., Molina, M. C., Pastor, C., Cirera, L... Sánchez, E. (2012). Programa para la formación de acogedores en familia extensa. Barcelona: Fundación La Caixa.

Amorós, P., Pastor, C., Balsells, M. A., Fuentes-Peláez, N., Molina, M. C., \& Mateos, A. (2009). Programme de formation pour familles d'accueil. Impac sur la qualité de vie des enfant et la résilience familiale. In N. Nader-Grosbois (Ed.), Résilience, régulation et qualité de vie. Concepts, evaluation et intervention (pp. 187-193). Louvain: Presses universitaires de Louvain.

Balsells, M. A., Fuentes-Peláez, N., Mateo, M., Mateos, A., \& Violant, V. (2010). Innovación socioeducativa para el apoyo de adolescentes. Educar, 45, 133-148.

Bartolomé, M. (1986). La investigación cooperativa. Educar, 10, 51-78.

Bartolomé, M., \& Anguera, M. T. (1990). La investigación cooperativa: Vía para la innovación en la Universidad. Barcelona: PPU.

Bass, S., Shields, M. K., \& Behrman, R. E. (2004). Children, families and foster care: Analysis and recommendations. The Future of Children, 14, 4-29. doi:10.2307/1602752

Berrick, J. D., Barth, R. P., \& Needell, B. (1994). A comparison of kinship foster homes and foster family homes: Implications for kinship foster care as family preservation. Children and Youth Services Review, 16, 33-63. doi:10.1016/0190-7409(94) 90015-9

Broad, B. (2004). Kinship care for children in the UK: Messages from research, lessons for policy and practice. European Journal of Social Work, 7, 211-227.

Burnette, D. (1998). Grandparents rearing grandchildren: A school-based small group intervention. Research on Social Work Practice, 8, 10-27. doi:10.1177/104973159800800103

Camperos, M. (2008). La evaluación por competencias: Mitos, peligros y desafíos. Educere, 43, 805-814.

Child Welfare League of America. (1994). Kinship care: A natural bridge. Washington, DC: Author.

Davis, H., \& Day, C. (2010). Working in partnership: The family partnership model. London: Pearson.

Del Valle, J. F., Álvarez-Baz, E., \& Bravo, A. (2002). Acogimiento en familia extensa, Perfil descriptivo y evaluación de necesidades en una muestra del Principado de Asturias. Bienestar y Protección Infantil, 1, 33-56.

Del Valle, J. F., \& Bravo, A. (2003). Situación actual del acogimiento de menores en España. Oviedo: Universidad de Oviedo.

Del Valle, J. F., López, M., Montserrat, C., \& Bravo, A. (2009). Twenty years of foster care in Spain: Profiles, patterns and outcomes.

Children and Youth Services Review, 31, 847-853. doi:10.1016/j.childyouth.2009.03.007

Del Valle, J. F., López López, M., Montserrat, C., \& Bravo, A. (2010). El acogimiento familiar en España. Una evaluación de resultados. Madrid: Ministerio de Educación, Política Social y Deporte. 
Durán-Aponte, E., \& Durán-García, M. (2012). Competencias sociales y las prácticas profesionales. Vivencias y demandas para la formación universitaria actual. Cultura y Educación, 24, 61-76.

Echevarría, B. (2005). Competencia de acción de los profesionales de la orientación. Madrid: ESIC.

Ehrle, J., \& Geen, R. (2002). Kin and non-kin foster care: Findings from a national survey. Children and Youth Services Review, 24, 15-35. doi:10.1016/S0190-7409(01)00166-9

Farmer, E., Selwyn, J., \& Meakings, S. (2013). Other children say you're not normal because you don't live with your parents. Children's views of living with informal kinship carers: Social networks, stigma and attachment to carers. Child \& Family Social Work, 18, 25-34. doi:10.1111/cfs.12030

Fortín, A., \& Legault, M. (2009). Development of generic competencies: Impact of a mixed teaching approach on students' perceptions. Accounting Education, 19, 93-122. doi:10.1080/09639280902888195

Fuentes-Peláez, N., Amorós, P., Balsells, M. A., \& Pastor, C. (2010). A support program addressed to youth in kinship foster care from the resilience perspective. In E. J. Knorth, M. E. Kalverboer, \& J. Knot-Dickscheit (Eds.), Inside out. How interventions in child and family care work (pp. 267-271). Antwerp: Garant.

Fuentes-Peláez, N., Balsells, M. A., Fernández, J., Vaquero, E., \& Amorós, P. (2014). The social support in kinship foster care: A way to enhance resilience. Child and Family Social Work. doi:10.1111/cfs.12182

Geen, R. (2003). Foster children placed with relatives often receive less government help (Series A-59). Washington, DC: The Urban Institute.

Geen, R., \& Berrick, J. D. (2002). Kinship care: An evolving service delivery option. Children and Youth Services Review, 24, 1-14. doi:10.1016/S0190-7409(01)00165-7

Hegar, R., \& Scannapieco, M. (Eds.). (1999). Kinship foster care: Policy, practice and research. Oxford: Oxford University Press.

Kropf, N. P., \& Kolomer, S. (2004). Grandparents raising grandchildren: A diverse population. Social Work Faculty Publications, 13. Retrieved from http://digitalarchive.gsu.edu/ssw_facpub/13

Leos-Urbel, J., Bess, R., \& Geen, R. (2002). The evolution of federal and state policies for assessing and supporting kinship caregivers. Children and Youth Services Review, 24, 37-52. doi:10.1016/S0190-7409(01)00167-0

López-Larrosa, S. (2009). El sistema familiar ante el divorcio: Factores de riesgo y protección y programas de intervención. Cultura y Educación, 21, 391-402. doi:10.1174/113564009790002436

Marzo, M., Pedraja, M., \& Rivera, P. (2006). Las competencias profesionales demandadas por las empresas: el caso de los ingenieros. Revista de Educación, 341, 643-661. 
Mateos, A., Balsells, M. A., Molina, M. C., \& Fuentes-Peláez, N. (2012). The perception adolescents in kinship foster care have of their own needs. Review of Research and Social Intervention, 38, 25-41.

Mateos, A., Balsells, M. A., Pastor, C., Vaquero, E., \& Mundet, A. (2015). Risk factors and protection factors associated with kinship family care. Child and Adolescent Social Work Journal, 32, 417-427. doi:10.1007/s10560-015-0382-8

Molero, R., Moral, M., Albiñana, P., Sabater, Y., \& Sospedra, R. (2007). Situación de los acogimientos en familia extensa en Valencia. Anales de Psicología, 23, 193-200.

Montserrat, C. (2007). Kinship foster care: A study from the perspective of the caregivers, the children and the child welfare workers. Psychology in Spain, 11, 42-52.

Montserrat, C. (2012). Kinship care in Spain: Messages from research. Child \& Family Social Work, 19, 367-376. doi:10.1111/ cfs.12028

Montserrat, C., Casas, F., \& Malo, S. (2013). Delayed educational pathways and risk of social exclusion: The case of young people from public care in Spain. European Journal of Social Work, 16, 6-21. doi:10.1080/13691457.2012.722981

Palacios, J., \& Jiménez-Morago, J. (2007). Acogimiento familiar en Andalucía. Seville: Junta de Andalucía.

Parra-Ramajo, B. (2012). Estudio sobre los factores de cambio en grupos socioeducativos de familias de acogida extensa. Portularia, 12, 131-139.

Pastor, C., Amoros, P., Molina, M. C., \& Balsells, M. A. (2008). Social work educators in kinship Foster care. European Journal of Social Education, 14/15, 73-83.

Price, J. M., Chamberlain, P., Landsverk, J., Reid, J. B., Leve, L. D., \& Laurent, H. (2008). Effects of a foster parent training intervention on placement changes of children in foster care. Child Maltreatment, 13, 64-75. doi:10.1177/ 1077559507310612

Rodrigo, M. J., Máiquez, M. L., \& Martín, J. C. (2011). Buenas prácticas profesionales para el apoyo a la parentalidad positiva. Madrid: Federación Española de Municipios y Provincias (FEMP).

Rodrigo, M. J., Martin, J. C., Mateos, A., Pastor, C., \& Guerra, M. (2013). Impact of the 'Learning Together, Growing in Family' Programme on the professionals and attention to families services. Revista de Cercetare si Interventie Sociala, 42, 145- 165.

Rychen, S., \& Salganik, L. (Eds.). (2003). Las competencias clave para el bienestar personal, social y económico. Málaga: Aljibe.

Spencer, L., \& Spencer, S. (1993). Competence at work: Models for superior performance. New York, NY: John Wiley \& Sons.

Tejada, J., \& Navío, A. (2005). El desarrollo y la gestión de competencias profesionales: una mirada desde la formación. Revista Iberoamericana de Educación, 37(2). Retrieved from http://www.rieoei.org/deloslectores/1089Tejada.pdf

Tobón, S. (2006). Aspectos básicos de la formación basada en competencias. Talca: Proyecto Mesesup. Retrieved from http://www.uv.mx/facpsi/proyectoaula/documents/Lectura5.pdf 
Vacha-Hasse, T., Ness, C. M., Dannison, L., \& Smith, A. (2000). Grandparents raising grandchildren: A psychoeducational group approach. The Journal for Specialists in Group Work, 25, 67-78. doi:10.1080/01933920008411452

Vargas, F. (2000). De las virtudes laborales a las competencias clave: Un nuevo concepto para antiguas demandas. Boletín Cinterfor, 149, 9-23. 